\title{
Seed morphology in Euphorbia and its taxonomic applications: a case study in São Paulo, Brazil
}

\author{
Otávio Luis Marques da Silva ${ }^{1} \cdot$ Inês Cordeiro $^{1} \cdot$ Maria Beatriz Rossi Caruzo $^{2}$
}

Received: 18 August 2015/Accepted: 5 October 2015/Published online: 23 October 2015

(C) Botanical Society of Sao Paulo 2015

\begin{abstract}
Euphorbia L., with around 2000 species, is the biggest genus of Euphorbiaceae and one of the largest and most diverse genera within Angiosperms. It shows an almost cosmopolitan distribution and notable morphological diversity and is characterized by a pseudanthial inflorescence, the cyathium, which is unique to the genus. Along with its great morphological diversity in growth form, seed characters such as shape, testa ornamentation and presence or absence of caruncle are among its most notable and variable features. Given the potential utility of seed characters for species identification, we set to characterize the seeds from all known species (24) of Euphorbia occurring in the state of São Paulo, using photos and scanning electronic microscopy images. These species belong to three subgenera and seven sections of Euphorbia, and their morphological diversity is discussed in a phylogenetic context according to the most recent classification. Seed characters such as shape, size, testa ornamentation, and presence or absence of caruncle proved to be useful for identification of sections and for distinguishing closely related species.
\end{abstract}

Keywords Euphorbia subg. Chamaesyce Euphorbia subg. Esula · Euphorbia subg. Euphorbia - Seed coat . Systematics $\cdot$ Testa ornamentation

Otávio Luis Marques da Silva

otaviolmarques@gmail.com

1 Núcleo de Pesquisa Curadoria do Herbário SP, Instituto de Botânica de São Paulo, Avenida Miguel Stéfano 3687, São Paulo, SP CEP 04045-972, Brazil

2 Departamento de Ciências Exatas e da Terra, Universidade Federal de São Paulo, Rua Prof. Artur Riedel, 275, Diadema, SP CEP 09972-270, Brazil

\section{Introduction}

Euphorbia L., with about 2000 species, is the largest genus within Euphorbiaceae and is ranked as the fourth largest in Angiosperms (Govaerts et al. 2000; Frodin 2004). Its species are found throughout the world, but a remarkably higher diversity is found on arid habitats in the tropics (Govaerts et al. 2000; Radcliffe-Smith 2001). In Brazil, according to Steinmann et al. (2015), the genus is represented by relatively few species ( 64 spp.), but it shows a high degree of endemism (ca. $50 \%, 31$ spp.). Nevertheless, Brazil has the greatest number of native species when compared to other countries in South America (Steinmann 2013). In São Paulo state, Silva et al. (2014) registered 23 species, belonging to three subgenera and six sections, from which E. subg. Chamaesyce sect. Anisophyllum is the most species-rich group, with 11 species. In the state, the genus is best known for its common weeds, but Euphorbia species are also found in "cerrado" vegetation, seashore plains ("restingas"), high montane habitats and edge of forests.

Phylogenetic studies (Steinmann and Porter 2002; Bruyns et al. 2006; Zimmermann et al. 2010; Horn et al. 2012) have shown the monophyly of Euphorbia and made great advance on the understanding of its infrageneric relationships, with four subgenera currently recognized: E. subg. Athymalus (Peirson et al. 2013), E. subg. Esula (Riina et al. 2013), E. subg. Euphorbia (Dorsey et al. 2013), and E. subg. Chamaesyce (Yang et al. 2012). Although morphologically well characterized due to its typical pseudanthial inflorescence, the cyathium, many major structural characters within Euphorbia have shown to be highly homoplastic, such as, for example, the xeromorphic growth form and seed caruncle, which had 14 and 13 independent origins, respectively (Horn et al. 2012).

The genus exhibits an extraordinary diversity on both vegetative and reproductive characters (Horn et al. 2012). Seeds within Euphorbia possess great taxonomic and systematic value once they are extraordinarily diverse in its morphology (Morawetz et al. 2009, 2010a, b; Wagner et al. 2010, 2011a, b, 
c), being widely used on the circumscription of species and subspecies or varieties (Pahlevani and Akhani 2011; Salmaki et al. 2011; Hafford and Harris 2012; Can and Küçüker 2015; Pahlevani et al. 2015) and to characterize sections within the genus (Yang et al. 2012; Dorsey et al. 2013; Riina et al. 2013; Peirson et al. 2013). Hence, compared to some vegetative and floral characters, seeds may show less phenotypic diversity and impact from environmental conditions (Zorić et al. 2010). However, considering its usefulness for distinguishing taxa within Euphorbia, more micromorphological studies on seed diversity of its species are needed, especially in the light of the phylogenetic framework available for Euphorbia.

Here we present a characterization of seeds from 24 species of Euphorbia registered for the state of São Paulo, including Euphorbia hypericifolia, a weedy species recently recorded for the state. Our aims are to increase the knowledge of Euphorbia seed morphology, analyze the genus seed diversity in Sao Paulo within a phylogenetic context, and provide useful characters for species identification.

\section{Materials and methods}

Seeds from 24 species of Euphorbia recorded for the state of São Paulo were obtained during fieldwork or, when necessary, from herbarium specimens, mainly those deposited on the herbarium "Maria Eneida P. Kauffman Fidalgo" of the Instituto de Botânica, São Paulo (SP; abbreviation according to Thiers 2015). Twenty mature seeds from, at least, three specimens from each species were observed on a Zeiss Stemi DV4 stereomicroscope to analyze morphological variation (seed shape, size, testa ornamentation and caruncle) within species and thus elaborate the seed description for each one. However, for some species, as Euphorbia papillosa A.St.-Hil., fewer seeds were examined due to lack of field material and the scarcity of seeds in available herbarium specimens. Measurements were performed with a millimeter ruler and the terminology for testa ornamentation is that of Harris and Harris (2001).

Photographs of dorsal, ventral, lateral, and apical faces were produced using an Olympus Stylys Tough 6000 digital camera attached to a Zeiss Stemi DV4 stereomicroscope. Scanning electronic microscopy was carried out on a set of three selected seeds from only one specimen of each species using a PHILIPS XL 20 Series S/W, version 5.21, on the Núcleo de Pesquisa Microscopia Eletrônica de Varredura (Instituto de Botânica, São Paulo).

\section{Results and discussion}

The Euphorbia species studied are listed in Table 1, along with their infrageneric position (subgenus and section), seed morphology (shape, size, testa ornamentation and caruncle) and the voucher specimen utilized for the scanning electronic microscopy.
Identification key to the species of Euphorbia from São Paulo based on seed morphology

1 Seeds carunculate....................................2

- Seeds ecarunculate..................................... 3

2 Seeds prismatic, testa inconspicuously verrucose ... E. comosa - Seeds ovoid, testa with two longitudinal grooves on ventral face and alveolate on dorsal face ...... E. peplus 3 Testa smooth....................................... 4

- Testa variously ornamented $\ldots \ldots \ldots \ldots \ldots \ldots \ldots 7$

4 Seeds globose............................. potentilloides

- Seeds ovoid...........................................5

5 Seeds rounded in cross section..............E. papillosa

- Seeds 3-4-gonous in cross section......................6

6 Seeds $2 \times 1 \mathrm{~mm}, 3$-gonous in cross section.........

E. peperomioides

- Seeds 1-1.2 × $0.5 \mathrm{~mm}$, 4-gonous in cross section .. E. serpens

7 Testa with at least one transversal ridge..............8

- Testa without transversal ridge.......................15

8 Testa tuberculate (at least on the dorsal face)........9

- Testa not tuberculate..................................11

9 Seeds $3-3.5 \times 2.5-3$, tuberculate on both dorsal and ventral faces..............................E. zonosperma - Seeds $0.5-1.2 \times 0.5-1$, tuberculate only on the dorsal face.. 10 10 Seeds $0.5-0.8 \times 0.5 \mathrm{~mm} \ldots \ldots \ldots \ldots \ldots . . . .$. hypericifolia - Seeds $1-1.2 \times 0.8-1 \mathrm{~mm} \ldots \ldots \ldots \ldots \ldots . . . . . .$. . hyssopifolia

11 Seeds grayish............................. prostrata

- Seeds brown to pinkish .................... 12

12 Seeds 3-gonous in cross section............... . hirta

- Seeds 4-gonous in cross section......................13

13 Testa with irregular ridges............... ophthalmica

- Testa with regular ridges.............................14

14 Testa with 5-7 transversal ridges .... E. adenoptera

- Testa with 2-4 transversal ridges.......... E. thymifolia

15 Seeds rounded in cross section.....................16

- Seeds 3-4-gonous in cross section...................17

16 Seeds $3 \times 2 \mathrm{~mm}$, testa mammilate.........E. insulana

- Seeds $1 \times 0.5-0.8 \mathrm{~mm}$, testa alveolate...E. sciadophila

17 Testa verrucose or inconspicuously verrucose . . . 18

- Testa inconspicuously or irregularly tuberculate, rugose or inconspicuously or irregularly alveolate .. 20 18 Seeds $\leq 1,5 \mathrm{~mm}$ tall, 3 -gonous in cross section... E. elodes - Seeds $>1,5 \mathrm{~mm}$ tall, 4-gonous in cross section... 19 19 Seeds dark............................E. chrysophylla - Seeds brown to grayish....................E. cordeiroae 20 Seeds inconspicuously or irregularly tuberculate ...21 - Seeds rugose or irregularly or inconspicuously alveolate... 22 21 Seeds 3-gonous in cross section ...... E. heterophylla - Seeds 4-gonous in cross section.............E. bahiensis 22 Seeds 4-gonous in cross section............E. foliolosa - Seeds 3-gonous in cross section......................23 23 Seeds dark, testa rugose.................. rhabdodes - Seeds brown, testa irregularly alveolate..... E. setosa 


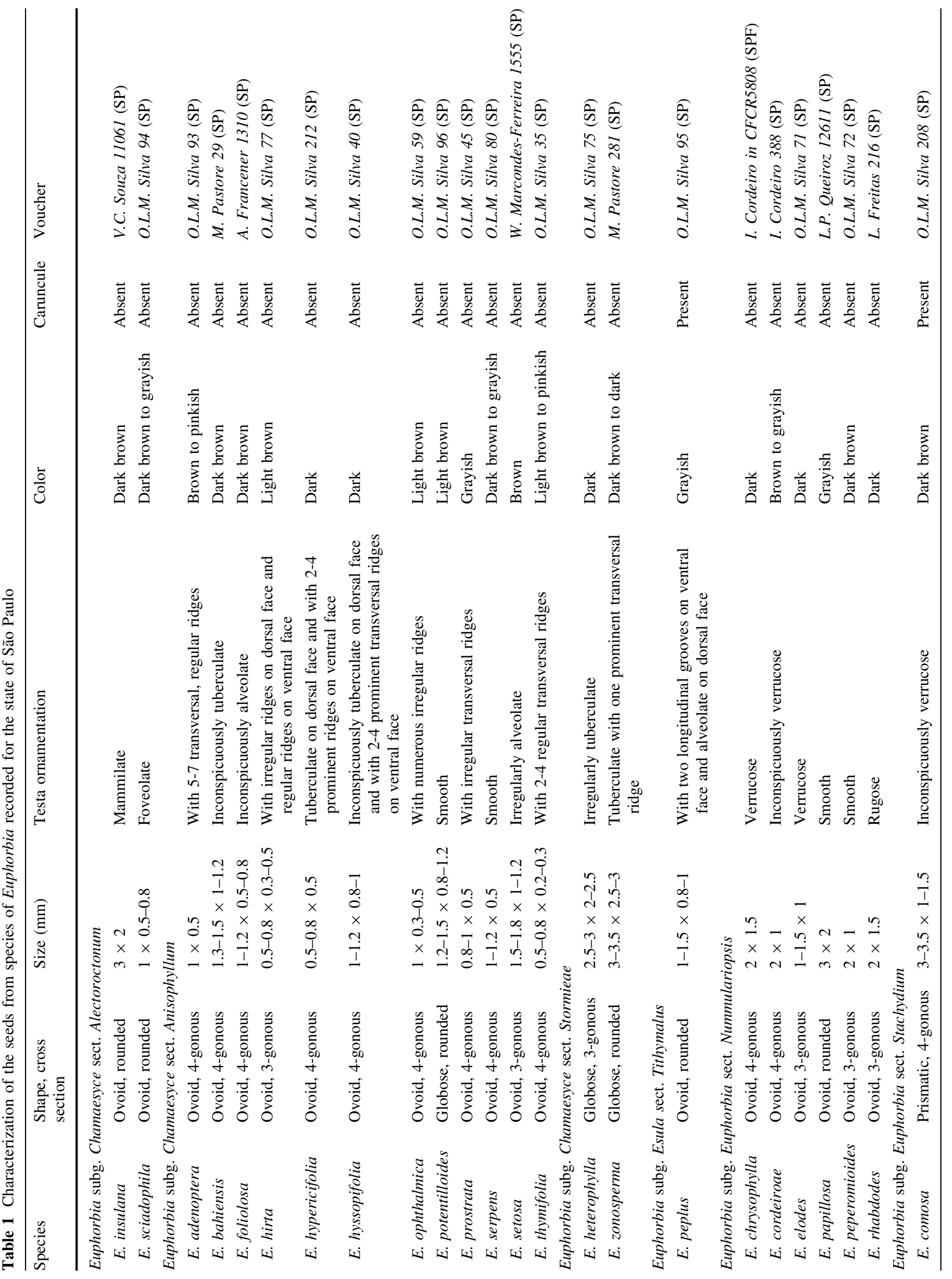



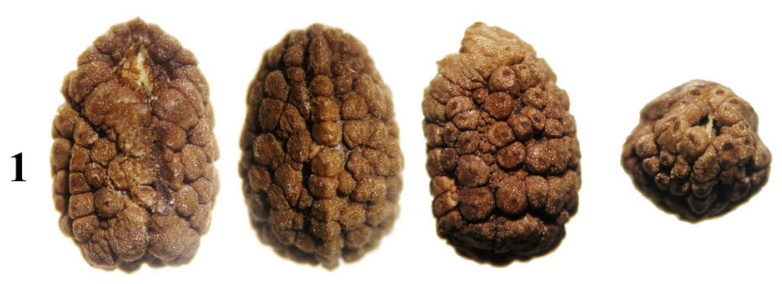

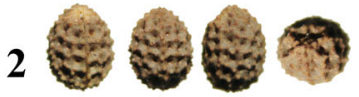
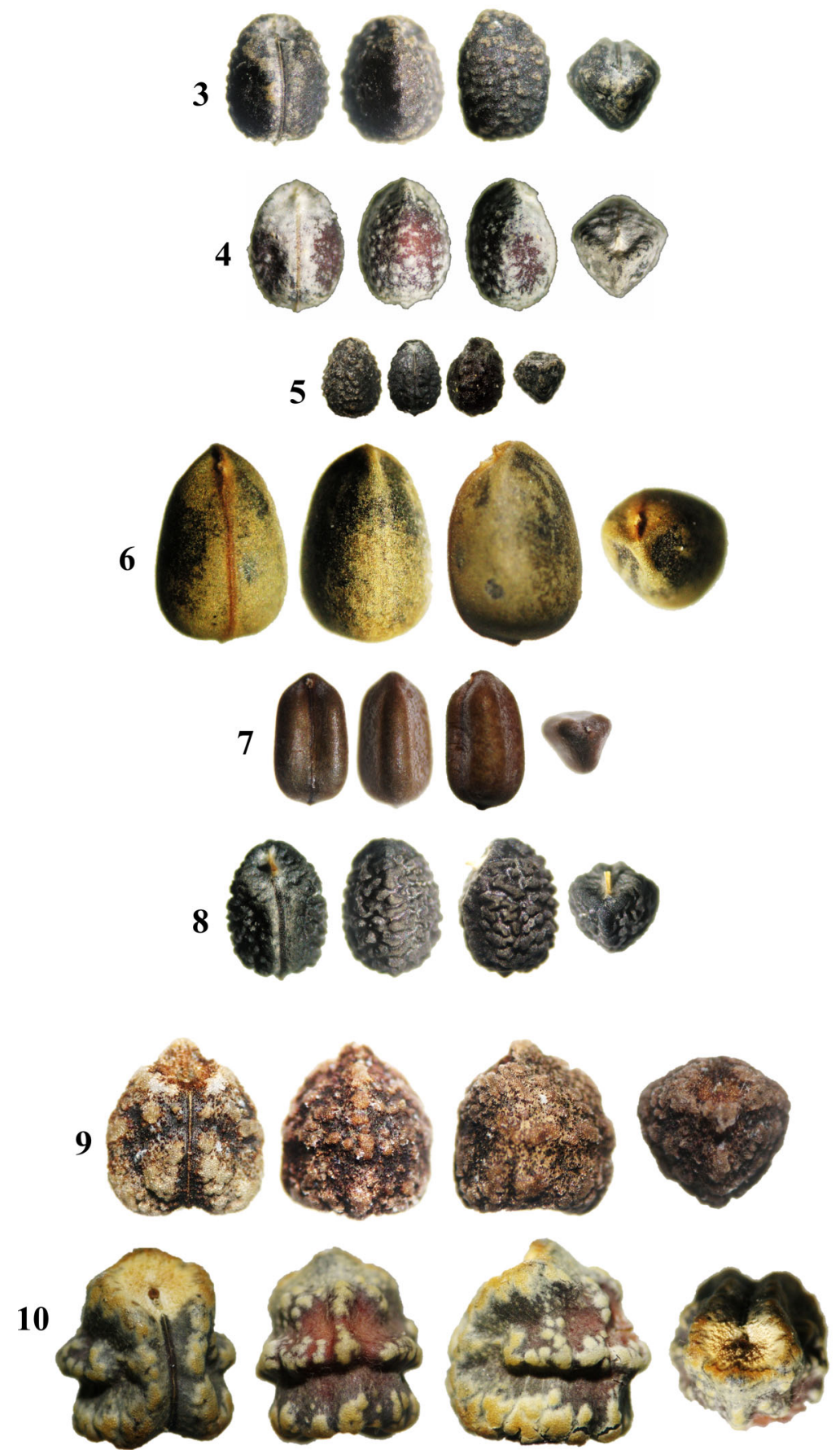

\section{"แื่อ}

12

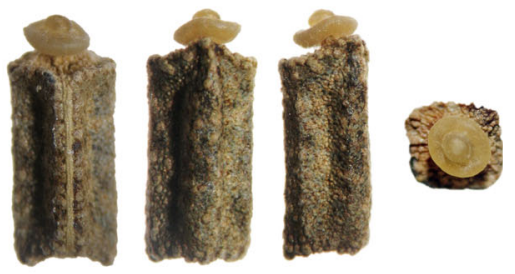

\section{C}

14

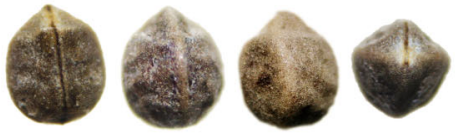

15 응 $\rightarrow$

\section{6 요응}

${ }_{17} 00$

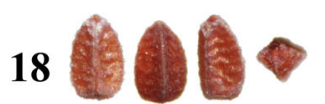

19

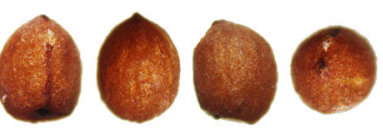

\section{0 년요}

\section{0}

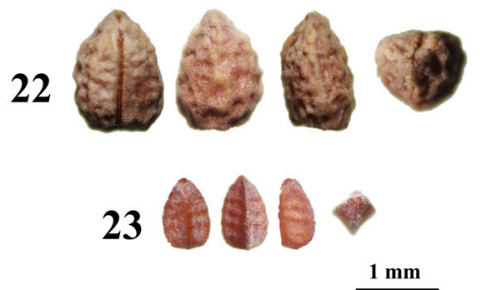


4Figs. 1-23 Seed morphology in stereomicroscope of species of Euphorbia from the state of São Paulo; ventral, dorsal, lateral, and apical view (left to right). 1-2 E. subg. Chamaesyce sect. Alectoroctonum-1 E. insulana. 2 E. sciadophila; 3-8 E. subg. Euphorbia. sect. Nummulariopsis-3 E. chrysophylla. 4 E. cordeiroae. 5 E. elodes. 6 E. papillosa. 7 E. peperomioides. 8 E. rhabdodes; 9-10 E. subg. Chamaesyce sect. Poinsettia-9 E. heterophylla. 10 E. zonosperma; 11 E. subg. Esula sect. Tithymalus-E. peplus; 12 E. subg. E. sect. Stachydium-E. comosa; 13-23 E. subg. Chamaesyce sect. Anisophyllum-13 E. adenoptera. 14 E. bahiensis. 15 E. foliolosa. 16 E. hirta. 17 E. hyssopifolia. 18 E. ophthalmica. 19 E. potentilloides. 20 E. prostrata. 21 E. serpens. 22 E. setosa. 23 E. thymifolia. (photos: O.L.M. Silva)

Seeds vary in size (from less than $1 \mathrm{~mm}$ up to $3 \mathrm{~mm}$ long), shape (globose, ovoid or prismatic and rounded or 3-4-gonous in cross section), and presence/absence of caruncle. However, the most fascinating diversity, and consequently the most important character for species identification, is observed on testa ornamentation, in which possible character states are smooth, variously tuberculate, alveolate, rugose, mammilate or verrucose, or with regular or irregular transversal ridges (Figs. 1-23).

Only two species have carunculate seeds: Euphorbia comosa Vell (Figs. 12, 24, 25) and E. peplus L. (Figs. 11, 26, 27). Both species belong to different infrageneric groups (see Table 1). They may be easily distinguished from each other by seed size (3-3.5 $\times 1-1.5$ in $E$. comosa vs. $1-1.5 \times 0.8-1$ in E. peplus) and testa ornamentation (inconspicuously verrucose in $E$. comosa vs. with two longitudinal grooves on ventral face and alveolate on the dorsal face in E. peplus), besides differences between the caruncles themselves (rounded with a globose central projection on $E$. comosa vs. conical in $E$. peplus).

Species from Euphorbia subg. Euphorbia sect. Nummulariopsis (namely E. chrysophylla [Klotzsch and Garcke] Klotzsch ex Boiss. (Figs. 3, 28, 29), E. cordeiroae P.Carrillo \& V.W. Steinm. (Figs. 4, 30, 31), E. elodes Boiss. (Figs. 5, 32, 33), E. papillosa (Figs. 6, 34, 35), E. peperomioides Boiss. (Figs. 7, 36, 37) and E. rhabdodes Boiss. (Figs. 8, 38, 39) show a variety of testa ornamentation that ranges from smooth in E. peperomioides and E. papillosa to variously verrucose or rugose in the others species. Identification of these species in São Paulo rely greatly on vegetative characters (Silva et al. 2014) due to the high conservatism of cyathial characteristics. However, our observations show that testa ornamentation provide useful characters when distinguishing these species.
The peculiar seeds from Euphorbia subg. Chamaesyce belong to sections represented by few species in São Paulo, as sect. Poinsettia (namely E. heterophylla Figs. 9, 40, 41, E. zonosperma Müll.Arg. Figs. 10, 42), sect. Alectoroctonum (namely E. insulana Vell. Figs. 1, 43, 44 and E. sciadophila Boiss. Figs. 2, 45, 46). Euphorbia heterophylla and E. zonosperma have quite similar seeds in shape and color, but these may be distinguished by size and testa ornamentation, with seeds of E. zonosperma ranging from 3 to $3.5 \times 2.5-3$ and $E$. heterophylla from 2.5 to $3 \times 2-2.5$, besides $E$. zonosperma having a prominent transversal ridge. On the other hand, E. insulana and $E$. sciadophila, despite belonging to the same section, show strongly different seed sizes and testa ornamentation. These species belonged to the former sections Dichlium and Cyttarospermum, respectively, on the classical treatments of Euphorbia from Boisser (1862) and Müller Argoviensis (1874). According to Yang et al. (2012), these species belong to different subclades of sect. Alectoroctonum based on morphology, although many characters frequently are convergent within sect. Alectoroctonum in its current broad delimitation.

Euphorbia subg. Chamaesyce sect. Anisophyllum is the richest one in number of species recorded for São Paulo (Silva et al. 2014) and one of the biggest sections within Euphorbia (Yang et al. 2012). Within this section, E. potentilloides Boiss. (Figs. 19, 47, 48) has remarkably different seeds when compared to other species from sect. Anisophyllum, being globose with a smooth testa (vs. ovoid and variously ornamented in the other species).

Prostrate species from Euphorbia subg. Chamaesyce sect. Anisophyllum (namely E. adenoptera Bertol. Figs. 13, 49, E. prostrata Figs. 20, 50, 51, E. serpens Kunth Figs. 21, 52, 53 and E. thymifolia L. Figs. 23, 54, 55), are characterized by seeds covered by a distinct hydrophilic whitish layer when observed under a stereomicroscope. With the exception of E. serpens that has smooth seeds, species from this informal group have seeds with regular or irregular ridges. Transversal ridges are also present in $E$. hyssopifolia L., E. hirta L. (Figs. 16, 56, 57) and E. ophthalmica Pers. (Fig. 18), and in these species, a combination of color and testa ornamentation is very useful to distinguish them.

Regarding the remaining species from sect. Anisophyllum in São Paulo, E. setosa (Boiss.) Müll.Arg. (Fig. 22) and E. foliolosa Boiss. (Figs. 15, 58, 59), they show inconspicuously alveolate seeds and may be distinguished by seed shape and size. On the other hand, seeds of Euphorbia bahiensis (Klotzsch \& Garcke) Boiss. (Figs. 14, 60), E. hyssopifolia (Figs. 17, 64) and E. hypericifolia 

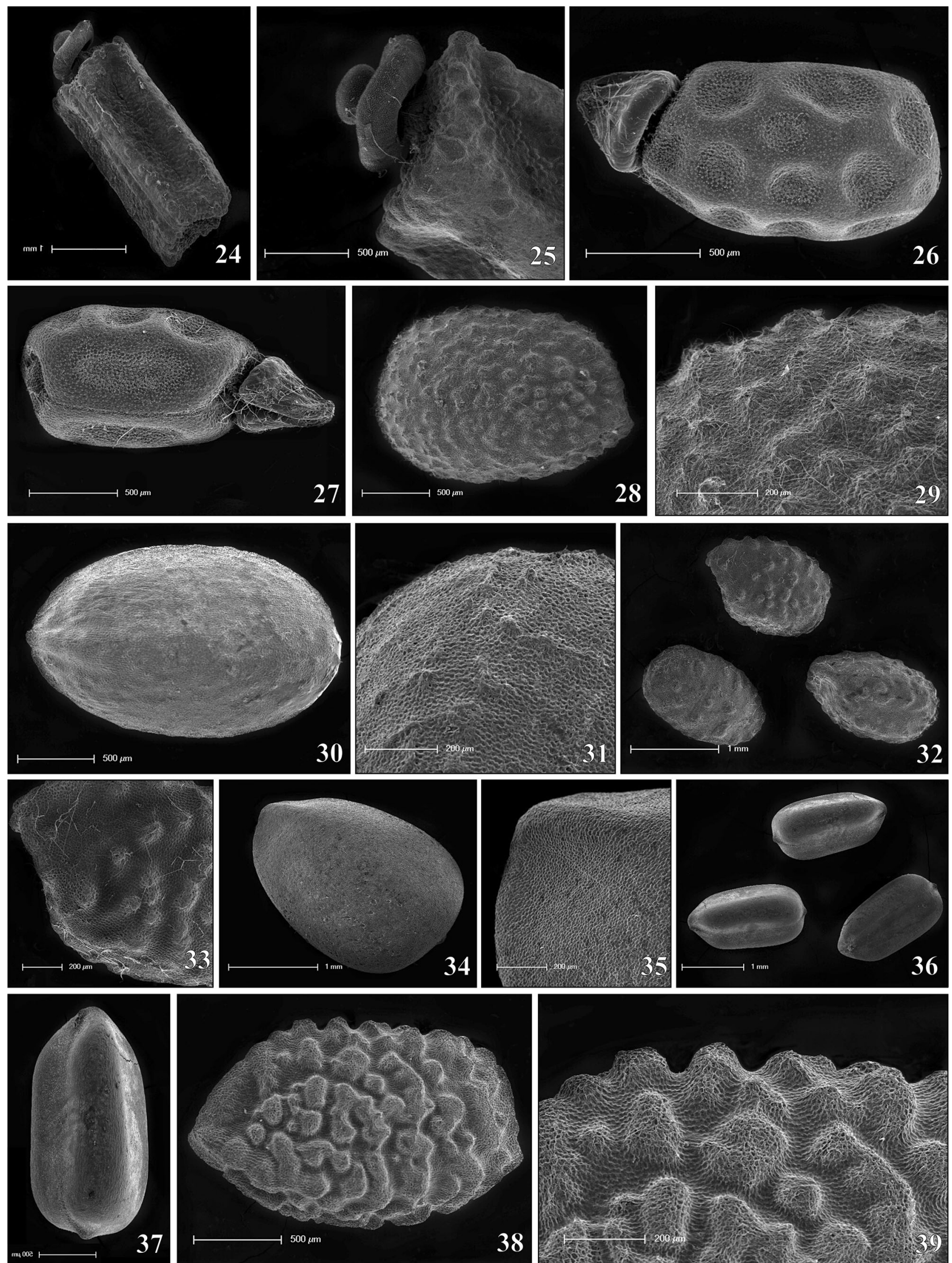

38

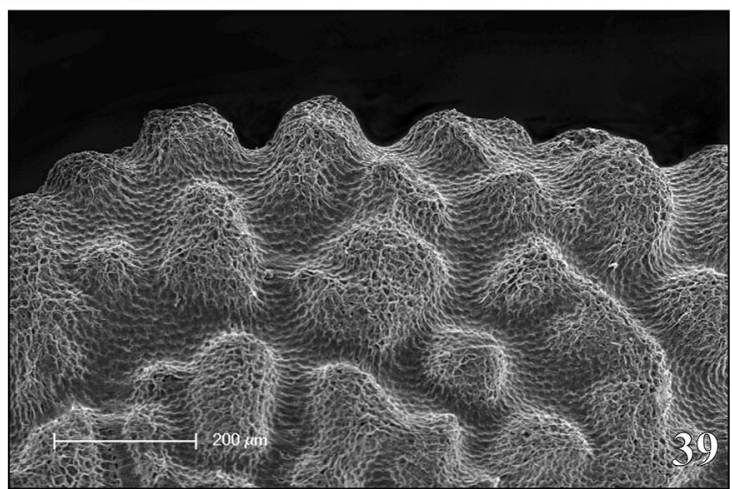


4Figs. 24-39 SEM of seeds from species of Euphorbia subg. Euphorbia sect. Stachydium and E. subg. Esula sect. Tithymalus. $\mathbf{2 4}$ seed of E. comosa. 25 detail of seed testa ornamention and caruncle of E. comosa. $\mathbf{2 6}$ seed of E. peplus. 27 detail of testa ornamentation and caruncle of E. peplus. $\mathbf{2 8}$ seed of E. chrysophylla. $\mathbf{2 9}$ detail of testa ornamentation of E. chrysophylla. $\mathbf{3 0}$ seed of E. cordeiroae. $\mathbf{3 1}$ detail of testa ornamentation of E. cordeiroae. 32 seeds of E. elodes. 33 detail of testa ornamentation of E. elodes. $\mathbf{3 4}$ seed of E. papillosa. $\mathbf{3 5}$ detail of testa ornamentation of E. papillosa. 36 seeds of $E$. peperomioides. 37 detail of testa ornamentation of E. peperomioides. 38 seed of $E$. rhabdodes. 39 detail of testa ornamentation of $E$. rhabdodes. Voucher information for each species is provided in Table 1
(Figs. 61, 62, 63) have tuberculate testa. These three species are very similar, in vegetative, cyathial and seed characters, but the seeds are slightly different in size, which provides a useful character for species identification. Transversal ridges are present on the dorsal face in $E$. hypericifolia and E. hyssopifolia, but these species may be distinguished from other species with transversal ridges by their tuberculate testa.

Vegetative and floral characters furnish enough information for species identification, especially considering the phylogenetic diversity of Euphorbia found in the state
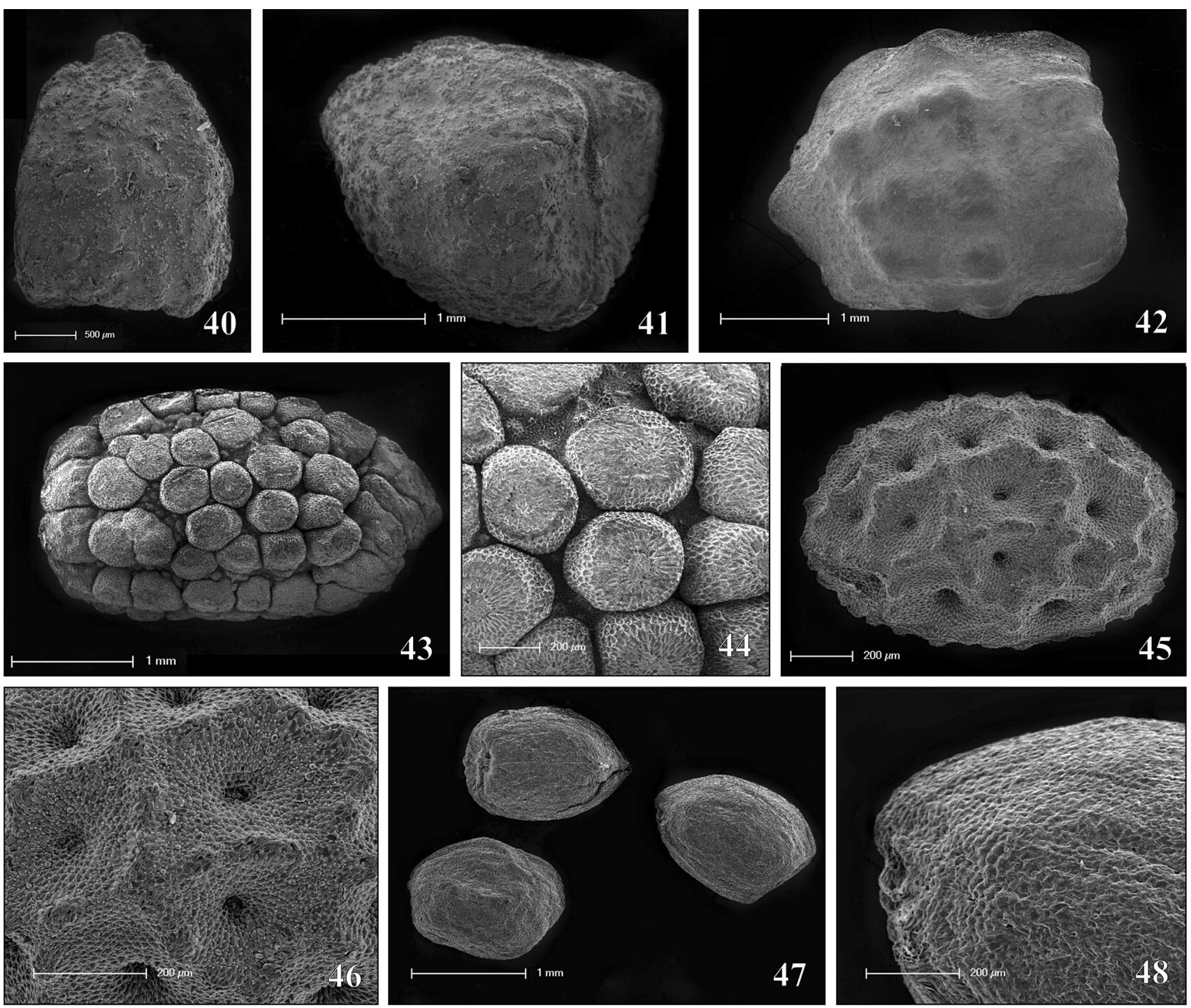

Figs. 40-48 SEM of seeds from species of Euphorbia subg. Chamaesyce sects. Poinsettia, Alectoroctonum and Anisophyllum. $\mathbf{4 0}$ seed of E. heterophylla. 41 detail of testa ornamentation of E. heterophylla. 42 seed of E. zonosperma. 43 seed of E. insulana. 44 detail of testa ornamentation of E. insulana. $\mathbf{4 5}$ seed of E. sciadophila. $\mathbf{4 6}$ detail of testa ornamentation of E. sciadophila. $\mathbf{4 7}$ seed of E. potentilloides. $\mathbf{4 8}$ detail of testa ornamentation of $E$. potentilloides. Voucher information for each species is provided in Table 1 

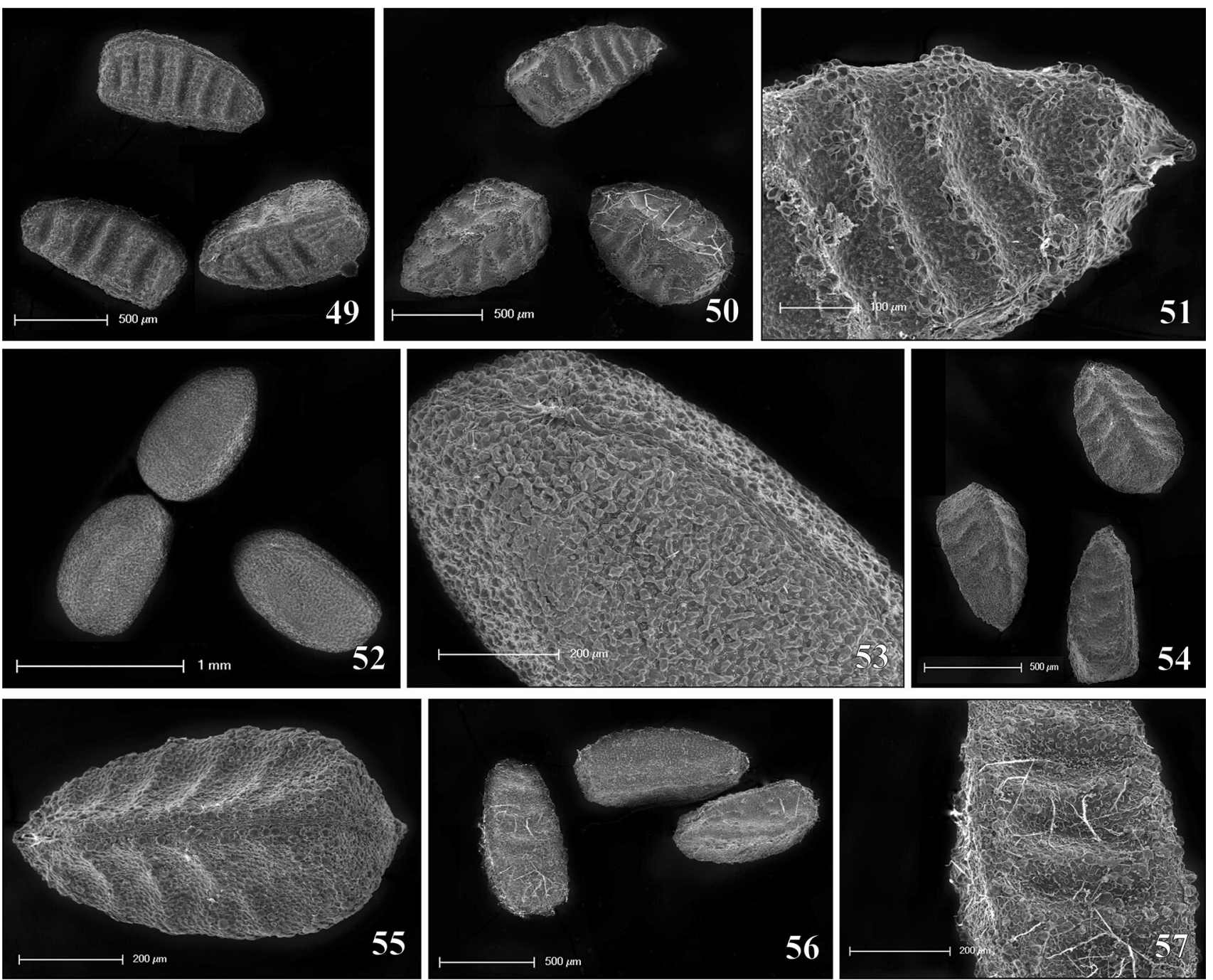

Figs. 49-57 SEM of seeds from species of Euphorbia subg. Chamaesyce sect. Anisophyllum. 49 seeds of E. adenoptera. 50 seeds of E. prostrata. $\mathbf{5 1}$ details of testa ornamentation of $E$. prostrata. $\mathbf{5 2}$ seeds of $E$. serpens. $\mathbf{5 3}$ detail of testa ornamentation of $E$. serpens. $\mathbf{5 4}$ seeds of $E$. thymifolia. 55 detail of testa ornamentation of E. thymifolia. 56 seeds of E. hirta. 57 detail of testa ornamentation of E. hirta. Voucher information for each species is provided in Table 1

of São Paulo, with many distantly related groups. However, seed characters provide additional information when distinguishing closely related species. Also, SEM images revealed that only few species show distinct processes covering the seeds (Figs. 51, 53), which form a hydrophilic whitish layer when observed under a stereomicroscope. This feature is so far known to be present in two groups (E. subg. Chamaesyce sects. Anisophyllum and Crossadenia; Yang et al. 2012) and, thus, represents an interesting trait in evolutionary terms because of its possible implications for seed dispersal or germination. 

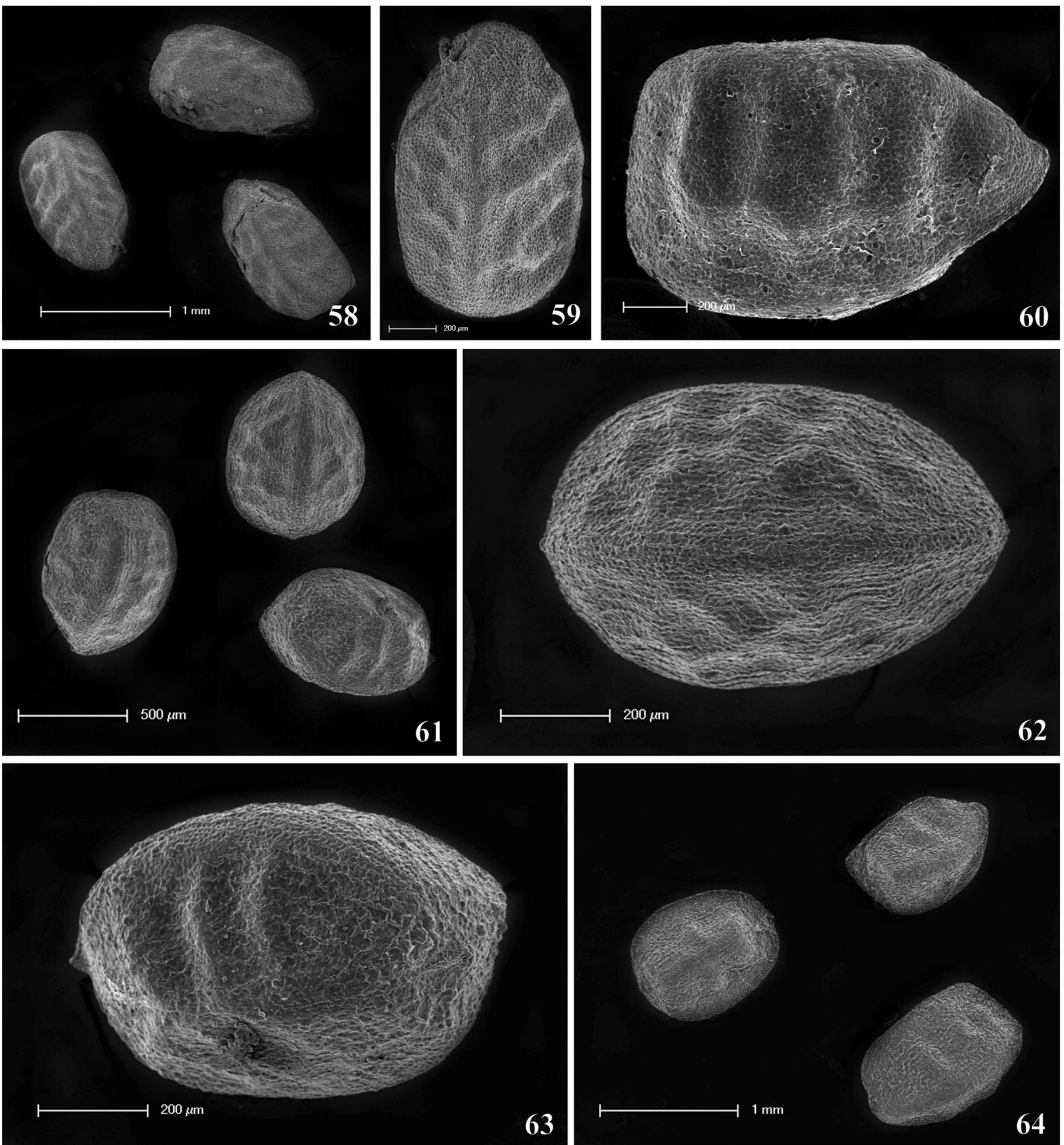

Figs. 58-64 SEM of seeds from species of Euphorbia subg. Chamaesyce sect. Anisophyllum. 58 seeds of E. foliolosa. 59 detail of testa ornamentation of E. foliolosa. 60 details of testa ornamentation of E. bahiensis. $\mathbf{6 1}$ seeds of E. hypericifolia. 62 detail of dorsal testa ornamentation of E. hypericifolia. $\mathbf{6 3}$ detail of ventral testa ornamentation of E. hypericifolia. $\mathbf{6 4}$ seeds of E. hyssopifolia. Voucher information for each species is provided in Table 1

Acknowledgments We thank Coordenação de Aperfeiçoamento de Pessoal de Nível Superior (CAPES) for the scholarship provided to the first author. We are also grateful to Marília Duarte for the discussion on terminology, to Luciana Benatti for the support on producing the SEM images and to the three anonymous reviewers. 


\section{References}

Boissier E (1862) Euphorbieae. In: Candolle ALPP (ed) Prodromus Systematics Universalis Regni Vegetabilis 15(2). Victor Masson, Paris, pp 3-188

Bruyns PV, Mapaya RJ, Hedderson T (2006) A new subgeneric classification for Euphorbia (Euphorbiaceae) in Southern Africa based on ITS and psbA-trnH sequence data. Taxon 55:397-420

Can L, Küçüker O (2015) Seed morphology and surface microstructure of some Euphorbia (Euphorbiaceae) taxa distributed in Turkey-in-Europe. Turk J Bot 39:449-457

Dorsey BL, Haevermans T, Aubriot X, Morawetz JJ, Riina R, Steinmann VW, Berry PE (2013) Phylogenetics, morphological evolution, and classification of Euphorbia subgenus Euphorbia. Taxon 62:291-315

Frodin DG (2004) History and concepts of big plant genera. Taxon 53:753-776

Govaerts R, Frodin DG, Radcliffe-Smith A (2000) World checklist and bibliography of Euphorbiaceae (and Pandaceae), vol. 2. Royal Botanical Gardens, Kew

Hafford DA, Harris WK (2012) A taxonomic revision of Euphorbia section Anisophyllym Roeper (Euphorbiaceae) in Australia. Austrobaileya 8:441-600

Harris JG, Harris MW (2001) Plant identification terminology: an illustrated glossary. Spring Lake Publishing, Payson

Horn JW, Van Ee BW, Morawetz JJ, Riina R, Steinmann VW, Berry PE, Wurdack KJ (2012) Phylogenetics and the evolution of major structural characters in the giant genus Euphorbia L. (Euphorbiaceae). Mol Phylogenet Evol 63:305-326

Morawets JJ, Riina R, Berry PE, Mayfield MH (2009) Euphorbia seed atlas part 1. Euphorbia World 5:27-29

Morawetz JJ, Riina R, Berry PE, Mayfield MH (2010a) Euphorbia seed atlas part 2. Euphorbia World 6:25

Morawetz JJ, Riina R, Berry PE, Mayfield MH (2010b) Euphorbia seed atlas part 4. Euphorbia World 6:21

Müller Argoviensis J (1874) Euphorbiaceae. In: Martius CFP, Eichler AW (eds) Flora Brasiliensis 11(2). Frid. Fleischer, München, pp 1-752

Pahlevani AH, Akhani H (2011) Seed morphology of Iranian annual species of Euphorbia (Euphorbiaceae). Bot J Linn Soc 167:212-234

Pahlevani AH, Liede-Schumann S, Akhani H (2015) Seed and capsule morphology of Iranian perennial species of Euphorbia (Euphorbiaceae) and its phylogenetic application. Bot J Linn Soc 177:335-377

Peirson JA, Bruyns PV, Riina R, Morawetz JJ, Berry PE (2013) A molecular phylogeny and classification of the largely succulent and mainly African Euphorbia subg. Athymalus (Euphorbiaceae). Taxon 62:1178-1199
Radcliffe-Smith A (2001) Genera Euphorbiacearum. Kew Publishing, Kew

Riina R, Peirson JA, Geltman DV, Molero J, Frajman B, Pahlevani A, Barres L, Morawetz JJ, Salmaki Y, Zarre S, Kryukov A, Bruyns PV, Berry PE (2013) A worldwide molecular phylogeny and classification of the leafy spurges, Euphorbia subgenus Esula (Euphorbiaceae). Taxon 62:316-342

Salmaki Y, Zarre S, Esser H-J, Heubl G (2011) Seed and gland morphology in Euphorbia (Euphorbiaceae) with focus on their systematic and phylogenetic importance, a case study in Iranian highlands. Flora 206:957-973

Silva OLM, Cordeiro I, Caruzo MBR (2014) Synopsis of Euphorbia (Euphorbiaceae) in the state of São Paulo, Brazil. Phytotaxa 181:193-215

Steinmann VW (2013) Three new species of Euphorbia subg. Chamaesyce (Euphorbiaceae) from Bolivia. Phytotaxa 114:23-32

Steinmann VW, Porter JM (2002) Phylogenetic relationships in Euphorbieae (Euphorbiaceae) based on ITS and ndhF sequence data. Ann Missouri Bot Gard 89:453-490

Steinmann VW, Caruzo MBR, Silva OLM (2015) Euphorbia In: Lista de Espécies da Flora do Brasil. Jardim Botânico do Rio de Janeiro. http://floradobrasil.jbrj.gov.br/jabot/floradobrasil/ FB17561. Accessed 15 May 2015

Thiers B (2015) Index Herbariorum: a global directory of public herbaria and associated staff. New York Botanical Garden's Virtual Herbarium. The New York Botanical Garden. http:// sciweb.nybg.org/science2/IndexHerbariorum.asp. Accessed 15 May 2015

Wagner B, Morawetz JJ, Riina R, Berry PE, Becker R, Moller A (2010) Euphorbia seed atlas-part 3. Euphorbia World 6:28-29

Wagner B, Morawetz JJ, Riina R, Berry PE, Becker R, Moller A (2011a) Euphorbia seed atlas-part 5. Euphorbia World 7:11

Wagner B, Morawetz JJ, Riina R, Berry PE, Becker R, Moller A (2011b) Euphorbia seed atlas-part 6. Euphorbia World 7:21

Wagner B, Morawetz JJ, Riina R, Berry PE, Becker R, Moller A (2011c) Euphorbia seed atlas-part 7. Euphorbia World 7:15

Yang Y, Riina R, Morawetz JJ, Haevermans T, Aubriot X, Berry PE (2012) Molecular phylogenetics and classification of Euphorbia subgenus Chamaesyce (Euphorbiaceae). Taxon 61:764-789

Zimmermann NFA, Ritz CM, Hellwig FH (2010) Further support for the phylogenetic relationships within Euphorbia L. (Euphorbiaceae) from nrITS and trnL-trnF IGS sequence data. Plant Syst Evol 286:39-58

Zorić L, Merkulov L, Luković J, Boža P (2010) Comparative seed morphology of Trifolium L. species (Fabaceae). Period Biol 112:263-272 